\title{
How does the governance of the executive branch operate in democratic Brazil? An analysis of the Center of Government
}

\author{
Pedro Luiz Costa Cavalcante ${ }^{\mathrm{l}}$ (D) and \\ Alexandre de Ávila Gomide \\ IDiretoria de Estudos do Estado, das Instituições e da Democracia, IPEA, Brasília, DF, Brasil. \\ KEYWORDS: center of government; governance arrangement; policy coordination; democracy; Brazil.
}

\begin{abstract}
Introduction: This paper aims to analyze how the Center of Government (CoG) operates as units responsible for conducting the presidential agenda in contemporary Brazil. Materials and Methods: The study applied the theoretical approach of CoG as a governance arrangement and used qualitative and quantitative data to reach its objective. Besides the bibliographic review on the literature and official documents, the study synthesizes and deepens empirical data and information from a joint research project covering the period of political stability in Brazil, from 1995 to 2014, when elected presidents ended their terms. Results: The empirical findings confirm that $\mathrm{CoG}$ is a flexible and dynamic phenomenon. It puts a critical perspective on the normative "good governance" approach that overvalues its technical dimension and neglects its political aspect. Discussion: The inquiry results shed light on the importance of the relation between politics and policy, by demonstrating that CoG's configuration and functions vary due to multiple causes, each president's priority policy agenda is implemented with different strategies and; the prioritized policies follow a unique coordination logic inside the Brazilian federal government.
\end{abstract}

Received in June 30, 2020. Approved in November 2, 2020. Accepted in December 23, 2020.

\section{Introduction ${ }^{1}$}

${ }^{1}$ We would like to thank UN volunteer Christine McKenzie for proofreading this manuscript.
$\mathrm{T}$ he Center of Government $(\mathrm{CoG})$ consists of institutions and actors that provide direct support to the chief of the executive branch in steering and coordinating the government's strategic agenda (Cavalcante, 2018). It is not a new phenomenon in contemporary states, since; for more than a century in Anglo-Saxon and Latin American nations, President and Prime Minister have delegated responsibility to critical units for leading their government priorities (Fawcett \& Gay, 2005; Relyea, 2008; Bonvecchi \& Scartascini, 2011). Although with new terminology, the Center of Government has been gaining prominence among scholars, elected officials, and multilateral organizations in the context of increasing demands to the public sector. Governments are currently facing a set of critical policy challenges globally with continuous economic, political, social, and technological changes. In addition to that, increasing citizen expectations and demands for public services improvements pressure public officials to innovate in terms of governance arrangements to improve policy implementation and effectiveness.

Despite its importance, there is limited research regarding executive governance and policy coordination in Brazil. The bulk of the literature about the $\mathrm{CoG}$ comes from multilateral and auditing organizations, is primarily normative, descriptive, and based on different administrative contexts (Alessandro, Lafuente \& Santiso, 2013a, 2013b, 2014; OECD, 2014; 2016; Brazil, 2014a; $2014 \mathrm{~b} ; 2016)$. We diverge from this approach because it lacks sound, theoretical, evidence-based grounds on what the $\mathrm{CoG}$ is and how it works. 


\section{Research context}

The Center of Government (CoG) has gained prominence among scholars, elected officials, and multilateral organizations since the public sector faces a continuously set of critical policy challenges globally in a context of dynamic economic, political, social, and technological changes. In addition to that, increasing citizen expectations and demands for public services improvements pressure public officials to innovate in terms of governance arrangements to strengthen policy implementation and effectiveness.

\section{Evidence prior to the study}

Despite its importance, there is limited research regarding executive governance and policy coordination in Brazil. The bulk of the literature about the CoG comes from multilateral and auditing organizations, primarily normative, descriptive, and based on different administrative contexts. This approach generally lacks sound, theoretical, evidence-based grounds on what the CoG is and how it works. These efforts to emulate best practices aim to pressure the public administration for better performance and a higher accountability level. Nevertheless, by neglecting the democratic dynamics and the administrative realities, they may constrain the capacity to provide a feasible recommendation and tend to be ineffective or risky.

\section{Added value of this study}

This study addresses the framework and operational patterns of the CoG's governance arrangement from 1995 to 2014 , grounded in empirical research knowledge. It analyzes what is, in fact, the Center of Government, how it changes over time, its fundamental roles, and how CoG performs the formal and informal tasks in the complicated Brazilian political and administrative systems. The main conclusion is that the Center of Government is a flexible, complex, and dynamic governance arrangement that continually changes because of the presidential styles, policy goals, and political and economic conjuncture.

Despite its changeable framework, the chief of staff (Casa Civil), Ministry of Planning, and Ministry of Finance were always part of Brazil's CoG. These positions tend to be occupied chiefly by professionals with a technical profile and nonparty affiliation, followed by the president's party members. Among the typical functions, coordination, planning, and strategic management of the president's priority agenda are predominant in $\mathrm{CoG}$ activities. Nevertheless, the units' leadership and engagement vary due to the level of policy prioritization and the degree of empowerment given to them by the president.

\section{Implications of all the available evidence}

The paper puts into critical perspective the "good governance" understanding of the CoG. The findings raise some objections over reform packages imposed by external agents unaware of the variety of interpretations about the phenomenon and the institutional context in which the executive governance is embedded. Proposals based on best practices may foster and pressure the public administration for better performance and higher accountability. However, establishing a rigid framework and functions to the $\mathrm{CoG}$ by law can be innocuous and problematic. It ignores the urgency of the president's policy priorities and a world full of changeable social problems and pressures. Besides, the normative approach departs from a positivity embedded in a supposed consensus and, above all, from assumptions that adopting successful ideas and practices in disparate political and administrative realities would automatically accomplish the same results.

The CoG is not only a technical body but a political one. To build authority with the capacity to implement the president's agenda demands a high level of investment in resources, institutions, learning, and negotiation to coordinate critical stakeholders and relationships in and outside government. It is a matter of collective action, which always involves understanding the political dimension in co-creating solutions for the public sector. Therefore, this paper concludes that plastering the Center of Government can hamper the executive branch's capacity to cope with wicked problems, i.e., complex, transversal, and multi-causal issues, such as the current COVID-19 crisis, that calls for State responses that are not simplistic, in democratic societies and a rapidly changing environment.

This paper aims to analyze how the Center of Government works as units responsible for conducting the presidential agenda in democratic Brazil. To answer these questions, we analyze empirical information about $\mathrm{CoG}$ at the federal level and synthesize a research project's findings analyzing the 1995 to 2014 period. We have chosen this period, including three different presidents and five terms, because it is a time of power alternation with no political turmoil in contemporary Brazil. Therefore, the analyzed period covers the twenty years after the democratization that elected presidents ended their terms.

It is worth mentioning that Brazil is a case of a complex and dynamic democracy with political-institutional characteristics, such as coalitional presidentialism, federalism, autonomous control and oversight agencies, and social 
participation in policymaking. These characteristics tend to generate centrifugal effects and fragmentation of the governmental machinery, which poses considerable challenges to the Center of Government.

The paper's main argument is that the $\mathrm{CoG}$ is a flexible governance arrangement. In other words, it is complex, dynamic, and flexible, varying in terms of configuration, functions, and governance mechanisms to steer the president's priority policy agenda. These features change for several reasons, such as presidential styles, policy goals, and political and economic conjuncture. Therefore, efforts to emulate best practices based on a normative basis would pressure the public administration for better performance and a higher level of accountability. However, neglecting the democratic dynamics and the administrative realities not only constrains the capacity to provide feasible recommendation, but also may be ineffective, counter-productive, and even risky.

This paper is organized as follows. The next section (II) discusses the governance concept and its relation to the $\mathrm{CoG}$, followed by discussing the Center of Government's mainstream view (III). Then, the research questions are addressed through empirical evidence (IV). Lastly, the paper outlines its main findings and final remarks (V).

\section{The Center of Government as a governance arrangement}

In recent times, governance began to conquer a prominent place in policy and public administration literature (Levi-Faur, 2012). Despite the contested character of the concept, the proliferation of its use can be associated with at least three central aspects. The first one is related to bad performance and a lack of accountability on the traditional public administration model. Second, the side effects of New Public Management (NPM) reforms, such as excessive fragmentation, which demanded new forms of coordination (Bouckaert, Peters \& Verhoest, 2016). Finally, the process of interdependence and complexification of social problems. Therefore, 'the center struck back' is part of the third generation of administrative reforms, favoring centralized, integrated solutions, but with new mechanisms and instruments of coordination (Bouckaert, Peters, and Verhoest, 2016).

It is worth mentioning the efforts that have been made by multilateral organizations, such as the Organization for Economic Cooperation and Development (OECD) and the Inter-American Development Bank (IDB), to deepen knowledge about the CoG and to recommend actions on this topic (Alessandro, Lafuente \& Santiso, 2013a, 2013b, 2014, OECD, 2014, 2016). These efforts derive from the mainstream agenda of 'good governance' created by the World Bank (Santiso, 2001). However, such recommendations have received a set of criticisms for being naive and unrealistic. According to Pollitt and Hupe (2011), this is because they are considered rhetoric of fashion, generate vague and inaccurate interpretations, have a normative appeal, and suggest a consensus.

On a different approach, governance can be understood as a set of relational dynamics involving multiple actors (from the state and society) interconnected by formal and informal institutions to produce state policy capacities (Le Galès, 2011; Capano, Howlett \& Ramesh, 2015). In this vein, governance involves actors' interactions, rules, resources, mechanisms, and instruments organized in arrangements for steering policies and holding the government accountable. These governance arrangements may lead to efficiency and legitimacy in the political system, increasing the state capacity (Peters \& Pierre, 2010). It implies governance as an analytical perspective that sheds light on the relational dynamics among actors in state actions. 
Therefore, governance can be operationalized by institutional arrangements that organize and stabilize the relations between the different actors involved in policy processes (Gomide \& Pires, 2014; Pires \& Gomide, 2016). These arrangements are interpreted as diversified, depending on the actors' characteristics, institutional contexts, and historical legacies. Put differently, governance arrangements are path-dependent and vary according to political dynamics, stakeholders' strategies, and administrative resources involved.

Compared to prescriptive-formal perspectives, the analytical approach of governance as institutional arrangements has advantages for considering the indeterminate nature of the policy processes. Consequently, any policy's success and effectiveness can be due to its governance arrangement that can foster or harm the level of commitment, coordination, and cooperation needed. The same approach is appropriate to the Center of Government's analysis because it can be studied as a governance arrangement, in which coordination of collective action is the primary goal since it involves different public organizations and policy stakeholders (Filgueiras, 2019). Hence, CoG is not a trivial and easily replicable arrangement based on standard and normative recommendations.

\section{The official view of the Brazilian CoG}

Before addressing the research questions, we discuss in the present section how the mainstream view of the Center of Government has been currently adapted and adopted to the Brazilian federal administration.

In Latin America, existing studies show that CoGs differ in their ability to perform their essential functions. However, they are considered with low capacity by multilateral organizations, which leads to a series of recommendations to CoG improvements in the region (Alessandro, Lafuente, \& Santiso, 2013a, 2013b, 2014; OECD, 2014, 2016). We claim these pieces of advice could gain soundness by drawing from evidence-based information provided by empirical research.

Influenced by publications from multilateral organizations, the Brazilian Superior Court of Account (Tribunal de Contas da Uniao - TCU) suggested legal instruments to institutionalize the $\mathrm{CoG}$ in the country. It resulted in an enacted presidential decree and a legislative bill for "fostering good governance in the GoG, providing support and inducing its strengthening performance to a coherent implementation of the Executive's strategy" (Brazil, 2016: 11-12). Despite these goals' merits, we consider this initiative highly normative and with theoretical and empirical flaws that culminate in conceptual confusion about the Center of Government and its functions. The TCU's Guidelines for Assessing CoG's Governance indicates four assumptions for its performance:

i. Strategy: the result-oriented budgeting process should be linked with comprehensive governmental strategic planning;

ii. Coordination: to ensure the cooperation of ministries and agencies towards consistent policymaking, efficient, timely, and sustainable in terms of budget;

iii. Supervision: government plan must be continuously monitored by measuring performance indicators and stakeholders' results;

iv. Transparency: voluntary and transparent communication of activities and outcomes are useful to encourage performance improvement and accountability.

The TCU Guidelines also recommended a rigid and formal structure composed of all the presidency's units, Ministries of Planning and Economy, and 
the Council for Economic and Social Development. This view had shaped the legislative bill and the presidential decree. As one can see, the TCU's Guidelines presents a normative view of the CoG associated with the concept of 'good governance':

"In this context, the strengthening of the CoG towards good governance will be directly linked to the CoG's ability to perform its functions and increase the State's delivery capability. An efficient and effective CoG steers, monitors, and evaluates the State's deliveries. Suppose the GoG does not adequately fulfill its functions. In that case, the negative effects can lead to incoherence and/or antagonism between public policies, lack of strategic vision, poor formulation of objectives and policy targets, and inadequate follow-up and monitoring of the agenda' formulation (Brazil, 2016, 29-30)."

It is interesting to note that the Ministry of Planning and the Council have been extinct since 2019. The presidential administrative structure has also undergone several changes, but most important is that there is no evidence that the changes have affected the CoG's functions and performance.

\section{Empirical-based knowledge on the Brazilian CoG}

This section empirically analyzes the Brazilian Center of Government to understand how it is structured and how it functions. To do so, we employ empirical data from previous research on CoG (Cavalcante \& Gomide, 2018). The findings corroborate our hypothesis that the $\mathrm{CoG}$ is a dynamic and complex governance arrangement.

IV.1 What is the Center of Government?

The Center of Government is frequently classified in two ways: the narrow and the extended perspectives (Alessandro, Lafuente \& Santiso, 2013a). The first one, a.k.a. structural, refers to those units that are a formal part of the presidential structure or of the prime minister's office. In contrast, the second one, also known as the functional definition, includes units outside the presidential structure that perform typical Center of Government's functions such as policy coordination and monitoring (Alessandro, Lafuente, \& Santiso, 2013a; 2014; OECD, 2014).

However, how has the Brazilian CoG evolved during the 1995-2014 period? The number of units, especially ministries, in the studied period has increased. This increase is due to the growing complexity of governmental actions and the relevance of the CoG. Based on the structural definition, we collected information about the units that were formally established inside the presidency. Table 1 displays the CoG's compositional changes in Brazil, by presidential term.

Observing Table 1, one will notice that during President Cardoso's first administration the CoG consisted of eleven units: eight ministries and three councils. In Cardoso's second term, the coordinational dimension was strengthened to eight ministries versus five in the previous term, and introduced a specific secretariat for policy delivery - urban development. However, the main changes in the Center of Government occurred after the presidential turnover, i.e., during the Workers' Party (Partido dos Trabalhadores - PT) administrations of Lula Da Silva (2003-2010) and Dilma Rousseff (2011-2014).

PT is a typical left-wing party that had to rule the country with a broad party coalition. This fact has brought several changes in the configuration of the Center of Government. The first and most notorious was the increase of the number of ministries, and consequently, the number of units inside the CoG (if Cardoso's first term had eleven units, the average number of PT's administra- 
Table 1 - Center of Government Structures (1995-2014)

\begin{tabular}{lcccccc}
\hline & Coordination & Advisory & $\begin{array}{c}\text { Delivery } \\
\text { Units }\end{array}$ & $\begin{array}{c}\text { Center of Government } \\
\text { (Total) }\end{array}$ & $\begin{array}{c}\text { Cabinet } \\
\text { (Total) }\end{array}$ & $\begin{array}{c}\text { Councils* } \\
\text { Cardoso I }\end{array}$ \\
Cardoso II & 8 & 3 & 0 & 8 & 29 & 3 \\
Lula da Silva I & 9 & 1 & 1 & 10 & 14 & 3 \\
Lula da Silva II & 9 & 1 & 4 & 15 & 35 & 8 \\
Rousseff & 9 & 1 & 5 & 16 & 39 & 8 \\
\hline
\end{tabular}

Source: Brazilian Presidency (www.planalto.gov.br).

* Besides the councils, it also includes units without minister's status (Chief of Staff and Special Advisory) in the Presidency Structure.

tion were twenty-three). The same occurred regarding the ministerial cabinet composition since the number of ministers raised from 29 (Cardoso administration) to thirty-seven in Lula's terms to thirty-nine during Rousseff's administration.

A possible explanation for this increase relies on the Brazilian Executive coalition's features. While five parties composed Cardoso's administration with a high ideological convergence of center-right, PT's supporting coalition was quantitatively higher (around ten parties) and quite heterogeneous in ideological terms. Thus, the number of units in the cabinet increased as well as the coordination units (ministries and councils) in $\mathrm{CoG}$, which indicates a strategy of PT administrations to strengthen its control and to build governability in a broader and ideologically diverse coalition. Figure 1 displays the ideological index distance between the most extreme parties in the five administrations' coalitions analyzed. The indexes, measured by the Brazilian Legislative Survey, vary from 0 to 10 ; however, they have ranged from 1.1 to 8.89 in the last decades (Zucco, 2014).

In the same direction, Cavalcante and Batista (2018) drew from the analysis of the daily presidential schedule to demonstrate how the number of ministries increased in the CoG between 1995-2014. This was due to the growing complexity of governmental actions and the relevance of the Center of Government's typical functions, especially politics and policy coordination. The authors' innovative approach, based on how frequently ministries interacted with the president, proves that de jure or formal $\mathrm{CoG}$ is quite different from the $\mathrm{CoG}$ de facto, i.e. one that effectively participates in the president's routine agenda.

Figure 1 - The Presidential Coalitions' Ideology Distance

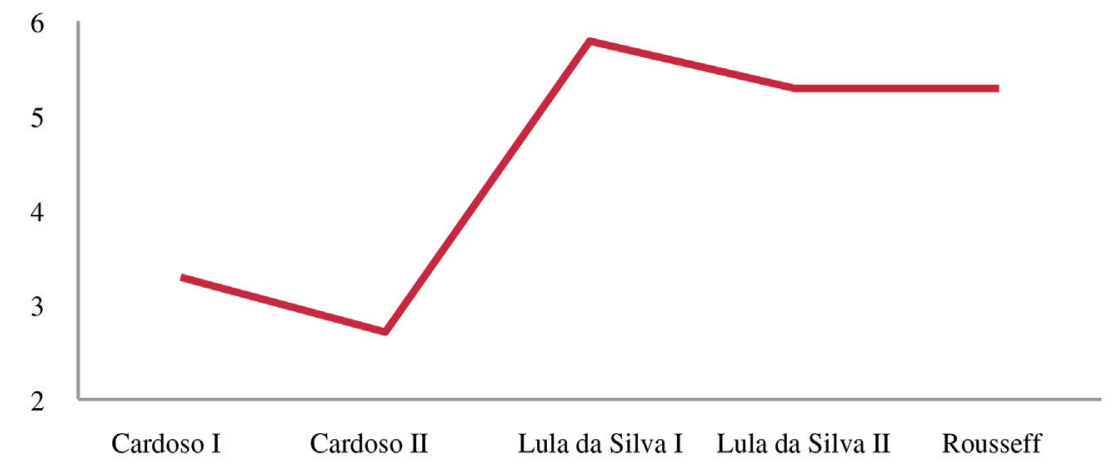

Source: Adapted from Zucco (2014). 
With a focus on the "Brazil without Poverty" Program (BWP) case, Mello (2019) provides an additional perspective of the CoG. She argues that the Ministry of Social Development (MDS), responsible for this priority policy under Rousseff's administration (2011-2014), is an example of a Center of the Government unit outside the presidential structure. Although MDS formally was not part of the $\mathrm{CoG}$, it has carried out typical CoG's activities, such as coordination, strategic management, performance monitoring, and accountability. The case demonstrates the dynamic and temporary nature of this governance arrangement, which may vary according to the presidential style and empowerment, legitimacy, and prioritization level embedded in the program management. When the program ended, the MDS lost the status of the Center of Government.

Furthermore, Pompeu and Lassance (2018) also find differences in functionalities inside the $\mathrm{CoG}$ by studying autobiographical information from Cardoso's first year (1995). The authors claim three different hubs in the Center of Government: Managerial, Economic, and Political. The first hub consists of the advisory team composed of government staff in charge of administrative and day-to-day policy operations. The economic CoG is composed of three ministries: economy, planning, and central bank. Lastly, the political hub has the president himself, the main protagonist, and the vice president and coalition party leaders in negotiation with Congress and conflict resolution.

Ministers' profiles differences in the president's strategies in defining CoG's command chain compared, when the chief of Executive gives autonomy to his/her cabinet to build a unified and centralized bureaucratic system, the situation in which to secure the governability president tends for units. In this case, ministries are primarily nonpartisan or from the president party and seldom from the coalition

IV.2 How the Center of Government operates

In this subsection, we explore the $\mathrm{CoG}$ in terms of its routine operations to demonstrate the complexity of its functions in a context of dynamic governance arrangement that employs a variety of mechanisms and instruments to coordinate the president's strategic agenda.

To begin with, what is a strategic agenda and how is it defined? The normative approach of $\mathrm{CoG}$ supports that an administration and its leaders have a strategic plan for the government and should implement it in convergence with the budgeting process (Brazil, 2016, p. 17-18). Nevertheless, the capacity to implement it effectively faces two crucial challenges. First, government strategy is not static, visible, and exclusive (Capano, Howlett, \& Ramesh, 2015). Even though documents might indicate the priority policy goals (such as the president's electoral agenda and the Pluri-annual Plan - PPA), they are not mandatory. De Toni (2018) addresses these issues by investigating how the president builds policy priorities by testing three hypotheses. First, the CoG's priorities stem from the electoral platform. Second, the mandatory PPA's formulation in each term's first year influences the president's strategic agenda formation. Finally, studies of perspective, long-term, and foresight scenarios inspire agenda formation. The findings confirm the first hypothesis of electoral programs' substantive influence and the coalition leading party, although not linearly since the process also involves economic constraints and political bargaining. As for the PPA, De Toni identifies a dissonance between the institutional agenda presented in these plans and its practical priorities. Likewise, prospective studies do not affect the strategic agenda. In short, the presidential agenda is a dynamic equation grounded in a continuous decision-making process that considers the political contest in a democratic environment and the scenarios of uncertainties and other social and economic constraints. 
Regarding the mechanisms and instruments used by the CoG to steer the strategic agenda, Cavalcante, Gomide, and Barbosa (2019) compared Da Silva's and Rousseff's administration priority policies, examining how the Center of Government coordinated them. The findings show that the priority policies were coordinated mainly by informal and ad hoc instruments due to the government's dynamism and urgency. The authors emphasize that hierarchical coordination mechanisms, often placed by the literature as the most important in the task-alignment strategies, were conjugated with network type mechanisms, given the constant search for trust, negotiation, and collaboration inside the government. Regarding the levels of coordination achieved (Metcalfe, 1994), the pieces of evidence suggest that the Chief of Staff (Casa Civil) and the ministers empowered by the president continuously arbitrate conflicts in the cabinet (negative coordination). However, the definition of priorities and national strategy predominantly stem from the presidents' office.

Lameirão (2018) analyzed the role of the Chief of Staff in the CoG. She found that the unit had diverse configurations during the period analyzed and assumed diverse functions. Her study also demonstrates that the Chief of Staff has a secondary role as author of the executive law proposal (less than 5\%). However, it permanently examines all bills' content, conducts the final decision-making process, and is the primary locus of government coordination.

The coordination of the legislative agenda is also a crucial subject to the Center of Government. For this reason, Batista (2018) explores the Executive's governance strategies from an interactional approach, i.e., analyzing the degree of interaction between the president and the different actors in the executive branch. The approach demonstrates that the higher the CoG units' participation, the greater the ability to translate agenda priorities into the president's legislative propositions. An analysis of President Cardoso's (1995-2002) and Rousseff's (2011-2014) meeting schedule highlights different management styles. The former preferred a more collective interaction with his ministers, while the latter used direct meetings with line ministers, which suggests that Cardoso used a collegiate style and Rousseff used closer to a hierarchical one (Johnson, 1974).

Similarly, Lopez, Silva, and Borges (2018) analyzed the presidency's role especially the chief of staff - in the delegation and control of policies to the coalition partners. Their findings show that agenda setting is dual: one with the president's priority interest and the other with the line ministries' proposals. In both cases, the formulation process begins in line ministries, with CoG performing a reactive or ex-post control. The chief of staff operates as a gatekeeper for the president, to which extent it decentralizes the bills' formulation, mediates conflicts, and refines the proposal before sending them to Congress.

The policy coordination with other levels of government is also an essential task in Brazilian federalism. To address this subject, Lotta and Freitas (2018) examined the coordination of federal policy initiatives during the period 20032014. The authors claim that the federal government has undertaken deliberate actions to strengthen the federative coordination to produce cooperation. The coordination efforts (mechanisms and instruments) aimed to promote long-term cooperation, transparency, and inter-sectoral coherence. The main protagonist of these actions was the Head for Federative Affairs (Subchefia de Assuntos Federativos - SAF), situated in the presidency. They demonstrate how effective SAF was in building key multilevel governance projects during which the president empowered the unit.

The relationship between State and society is also a salient task of CoG. It involves mechanisms of coordination, accountability, and communication. In this sense, Karam, Avelino, and Fonseca (2018) prove that General Secretariat 
(Secretaria Geral) and the Council for Economic and Social Development (CESD), both of which reside in the presidency, led a prominent role in social participation policy from 2003 to 2014. A social participation policy was formulated and implemented through a long process of debates, conflicts, and negotiations involving ideas, interests, and strategies of diverse social actors mediated by the CoG. The authors highlighted differences between the rules of consolidation and divergence in the interaction with other civil society actors. In sum, the main finding was how complex, mutable and diverse the Center of Government is since it was continuously busy with dissonances and disagreements from inside and outside the executive branch, reinforcing the dynamic perspective of governance (Capano, Howlett \& Ramesh, 2015). If the priority agenda is much more complicated than the normative view tends to report, the same should be expected regarding managing the Center of Government's presidential priorities. In this regard, Magalhaes and Couto (2018) analyzed the mechanisms and instruments designed to implement two major infrastructure investment programs: Brazil in Action (Brasil em Acao) and the Growth Acceleration Program (Programa de Aceleracao do Crescimento - PAC), during the Cardoso and Da Silva administrations, respectively. They part from the assumption that, although each president's CoGs had the same embedded function, they played their roles differently. The empirical findings are quite impressive. First, in either case, the program management tends to be more fluid and flexible than static and unique. Different leadership styles have also led to different approaches to priorities management.

Moreover, new tools and processes were created based on ideas derived from the professional and political experiences and learning of the $\mathrm{CoG}$ 's members. The Brazil in Action program (PAC) aimed to speed up the hierarchical relations between the line ministries and the coordination units through process improvement and staff training. In contrast, PAC built more horizontal and collective strategies to identify and overcome bottlenecks in the project selection and implementation. In sum, the authors conclude that similar political and administrative contexts were not barriers to how the Center of Government operates in different governance arrangements.

\section{Concluding Remarks}

This paper advances the understanding of how the Executive branch functions in Brazil. We addressed the framework and operational patterns of the CoG's governance arrangement, discussing, grounded in empirical evidence and research knowledge. The focuses direct to what are, in fact, the Center of Government, how it changes over time, what are its fundamental roles and, above all, how the Center of Government performs the formal and informal tasks in the complicated Brazilian political and administrative systems.

Our main argument is that the $\mathrm{CoG}$ is a flexible, complex, and dynamic governance arrangement that continually changes because of the presidential styles, policy goals, and political and economic conjuncture. In short, we can synthesize these research findings:

- The composition of the CoG is not static and varied during each analyzed period. It changes mainly due to the policy agenda prioritized by the presidents. However, the chief of staff, Ministry of Planning, and Ministry of Finance were always part of the CoG.

- The Center of Government units tend to be governed by professionals with a technical profile and nonparty affiliation, followed by the president's party members. 
- Among the typical functions, coordination, planning, and strategic management of the president's priority agenda are predominant in CoG activities. Nevertheless, the units' leadership and engagement vary due to the level of policy prioritization and the degree of empowerment given to them by the president;

- The role of informal coordination instruments is as important as the formal ones, and the employment of governance mechanisms (hierarchy, market, and networks) changes according to the policy issue and the president's management style;

- The strategic agendas are usually defined by the president, incorporating not only the guidelines of the electoral platform but, above all, always adjusting to the bargaining game of the coalition's political base and economic and social constraints;

- The CoG's relationships with civil society and other government levels (states and municipalities) vary according to the presidential style and the characteristics of the policies involved.

The research put into critical perspective the "good governance" understanding of the Center of Government, considering it naïve and unrealistic once it overvalues the object's normative dimension and neglects its political feature in a democratic regime.

The findings raise some objections over reform packages imposed by external agents unaware of the variety of interpretations about the phenomenon and the institutional context in which the executive governance is embedded. Proposals based on best practices may foster and pressure the public administration for better performance and higher accountability; however, establishing a COG in law or decree can be innocuous, counter-productive, and risky as it ignores the urgency of the president's policy priorities and a world full of changeable social problems and pressures. Besides, the normative approach departs from a positivity embedded in a supposed consensus and, above all, from assumptions that adopting successful ideas and practices in disparate political and administrative realities would automatically accomplish the same results.

The 'governance mechanisms' recommended by the TCU's Guidelines for the Brazilian federal administration are already included in the CoG's usual functions, but they cannot be regulated since its governance arrangement is relational and contextual. It includes multiple actors interconnected by formal and informal institutions and employs various mechanisms and instruments to coordinate their actions. Therefore, the CoG is not only a technical object but also a political one. To build authority with the capacity to implement the president's agenda demands a high level of investment in resources, institutions, learning, and negotiation to coordinate in and outside government players. It is a matter of collective action, which always involves understanding the political dimension for solutions co-creation for the public sector. Another aspect that stands out in this discussion involves the vastly disproportionate emphasis given to the supposed need to increase public administration's institutional control to the detriment of other dimensions. The control must be better balanced with other crucial affairs, such as partnership and cooperation, bureaucratic capacity building, and innovation culture.

To sum up, this paper concludes that plastering the Center of Government can hamper the executive branch's capacity to cope with wicked problems, i.e., complex, transversal, and multi-causal issues, such as climate changing, immigration and the current COVID-19 crisis, which calls for State responses that are not simplistic, in democratic societies and a rapidly changing world. 
The next step of the future research agenda points to the investigation of $\mathrm{CoG}$ as an independent variable or explanation for the policy governance outputs and outcomes. In other words, how the framework of a given Center of Government impacts (positively or negatively) a particular policy's performance in the executive branch. The analyses could focus on comparisons at subnational levels and between countries in the same region, such as Latin America. The studies that acknowledge the diversity of institutional factors that determine the executive governance framework tend to be more realistic and appropriated to provide insights into a qualified debate about how coordination and management of presidents' priority agenda work and subsidize recommendations for their performance improvement.

Pedro Luiz Costa Cavalcante (cavalcante.pedro@gmail.com) é doutor em Ciência Política pela UnB e Especialista em Políticas Públicas e Gestão Governamental no Instituto de Pesquisa Econômica Aplicada - Ipea.

Alexandre de Ávila Gomide (alexandre.gomide@ipea.gov.br) é Doutor em Administração Pública e Governo pela Fundação Getulio Vargas (FGV-SP) e membro da carreira de planejamento de pesquisa do Instituto de Pesquisa Econômica Aplicada (IPEA).

\section{References}

Alessandro, M., Lafuente, M., \& Santiso, C. (2013a) The role of the Center of Government. A literature review. Inter-American Development Bank. Technical Note, $\mathrm{N}^{\circ}$ 581. Washington: IDB.

Alessandro, M., Lafuente, M., \& Santiso, C. (2013b) Strengthening the Center of Government in Latin America and the Caribbean. Inter-American Development Bank. Technical Note, № 591. Washington: IDB.

Alessandro, M., Lafuente, M., Santiso, C. (2014) Governing to deliver: reinventing the Center of Government in Latin America and the Caribbean. Washington, DC: Inter American Development Bank IDB.

Batista, M. (2018) Como Governam os Presidentes: A Governança do Executivo e a Formulação da Agenda Legislativa. In: Instituto de Pesquisa Econômica Aplicada - Ipea (2018) O Presidente e seu Núcleo de Governo. Brasília. IPEA.

Bonvecchi, A., \& Scartascini, C. (2011) The Presidency and the executive branch in Latin America: What we know and what we need to know. Inter-American Development Bank Working Paper Series, No 283. IDB, pp. 1-72. Accessed on 14.02.2021: https://papers.ssrn.com/sol3/papers.cfm?ABSTRACT_id=1981544

Bouckaert, G., Peters, B. G., Verhoest, K. (2016) The coordination of public sector organizations. New York: Palgrave, Macmillan.

Capano, G., Howlett, M., \& Ramesh, M. (eds) (2015) Varieties of governance: Dynamics, strategies, capacities. Berlin: Springer.

Cavalcante, P. (2018) Núcleo, Centro de Governo, Centro Presidencial, Alto Governo: várias nomenclaturas e uma questão principal. Instituto de Pesquisa Econômica Aplicada (IPEA). Texto para Discussão (TD) No 2359.

Cavalcante, P. \& Batista, M. (2018) Composição e evolução do núcleo de governo no presidencialismo brasileiro. In: Cavalcante, P., \& Gomide, A. (org) O Presidente e seu Núcleo de Governo: a coordenação do Poder Executivo. Brasília: IPEA, pp. 59-87.

Cavalcante, P., \& Gomide, A. (orgs) (2018) O Presidente e seu Núcleo de Governo: a coordenação do Poder Executivo. Brasília: IPEA.

Cavalcante, P., Gomide, A., \& Barbosa, S. (2019) A Coordenação de programas prioritários sob a perspectiva do núcleo do governo federal (2007-2014). Instituto de Pesquisa Econômica Aplicada (IPEA). Texto para Discussão (TD) № 2440.

De Toni, J. (2018) Agenda estratégica, planejamento e programas eleitorais: cálculo político e pragmatismo. In: Cavalcante, P., \& Gomide, A. (org) O Presidente e seu Núcleo de Governo: a coordenação do Poder Executivo. Brasília: IPEA, pp. 353-380.

Filgueiras F. (2019) Governance, Brazil. In: Farazmand A. (ed) Global Encyclopedia of Public Administration, Public Policy, and Governance. New York, NY: Springer.

Gomide, A. D. Á., \& Pires, R. (2014) Capacidades estatais e democracia: a abordagem dos arranjos institucionais para análise de políticas públicas. In: Gomide, A. D. Á., \& Pires, R. (eds) Capacidades Estatais e Democracia. Arrajos Institucionais de Políticas Públicas. Brasília: IPEA, pp. 15-28.

Fawcett, P., \& Gay, O. (2005) The Centre of Government: No. 10, the cabinet office and HM Treasury. House of Commons Library.

Johnson, R. T. (1974) Managing the White House: An intimate study of the Presidency. New York: HarperCollins Publishers.

Karam, R., Avelino, D. \& Fonseca, I. (2018) Núcleo de Governo e Participação Social: O Caso da Política e do Sistema Nacional de Participação Social. In: Cavalcante, P., \& Gomide, A. (org) O Presidente e seu Núcleo de Governo: a coordenação do Poder Executivo. Brasília: IPEA, pp. 227-250. 
Lameirão, C. R. (2018) A Presidência em Movimento: Inovações, Variações Organizacionais e Frequências Decisórias da Casa Civil (1995-2015). In: Cavalcante, P., \& Gomide, A. (org) O Presidente e seu Núcleo de Governo: a coordenação do Poder Executivo. Brasília: IPEA, pp. 321-346.

Le Galès, P. (2011) Urban policies in Europe: what is governed? The new Blackwell companion to the city. In: Bridge, G., \& Watson, S. (eds) The new Blackwell companion to the city. Oxford: Wiley-Blackwell, pp. 747-758.

Levi-Faur, D. (2012) From "big government" to "big governance”. In: Levi-Faur, D. (ed) (2012) The Oxford handbook of governance. Oxford University Press, pp. 3-18.

Lopez, F, Silva, N. \& Borges, J. (2018) Governo Compartilhado? O Papel da Presidência na Formação e Coordenação da Agenda de Políticas do Executivo Federal (2003-2014). In: Cavalcante, P., \& Gomide, A. (org) O Presidente e seu Núcleo de Governo: a coordenação do Poder Executivo. Brasília: IPEA, pp. 289-318.

Lotta, S.G \& Freitas, M.N (2018) Análise dos Arranjos de Coordenação Federativa dos Núcleos de Governo de 2003 a 2014. In: Cavalcante, P., \& Gomide, A. (org) O Presidente e seu Núcleo de Governo: a coordenação do Poder Executivo. Brasília: IPEA, pp. 195-226.

Magalhaes, A.P \& Couto, L.F. (2018) Gestão de Prioridades e Núcleo de Governo: Os Casos do Brasil em Ação e do Programa de Aceleração do Crescimento. In: Cavalcante, P., \& Gomide, A. (org) O Presidente e seu Núcleo de Governo: a coordenação do Poder Executivo. Brasília: IPEA, pp. 381-407.

Mello, J. (2019) Núcleo de Governo de Fato: o caso do Plano Brasil Sem Miséria. In: Cavalcante, P., \& Gomide, A. (org) $O$ Presidente e seu Núcleo de Governo: a coordenação do Poder Executivo. Brasília: IPEA, pp. 139-167.

Metcalfe, L. (1994) International policy coordination and public management reform. International Review of Administrative Sciences, London, 60(2), 271-290.

Peters, G. \& Pierre, J. (orgs) (2010). Administração Pública: coletânea. São Paulo: Ed. Unesp; Brasilia: Enap.

Pires, R. \& Gomide, A. D. Á (2016) Governança, Arranjos institucionais e capacidades estatais na implementação de políticas federais. In: Menicucci, T, Gontijo, J. (org) Gestão e Políticas Públicas no cenário contemporâneo: tendências nacionais e internacionais. Rio de Janeiro: Editora Fiocruz, p. 101-130.

Pollitt, C. \& Hupe, P. (2011) Talking About Government Public Management Review, 13(5), pp. 641-658. DOI: $10.1080 / 14719037.2010 .532963$

Pompeu, J.C \& Lassance, A. (2018) A Presidência pelo olhar do Presidente: Uma análise do Núcleo de Governo a partir dos diários de Fernando Henrique Cardoso. In: Cavalcante, P., \& Gomide, A. (org) O Presidente e seu Núcleo de Governo: a coordenação do Poder Executivo. Brasília: IPEA, pp. 113-138.

Relyea, H. (2008). The executive office of the president: an historical overview. Wa-shington: Congressional Research Service.

Santiso, C. (2001) Good governance and aid effectiveness: The World Bank and conditionality. The Georgetown public policy review, 7(1), 1-22.

Zucco, C. (2014) The new meaning of left and right in Brazil: An analysis of the ideology of political elites since redemocratization. In: Biennial conference of the Brazilian Political Science Association (ABCP). Brasília.

\section{Others sources}

Brasil. (2014a). Tribunal de Contas da União. Referencial de Governança aplicável a órgãos e entidades da Administração Pública Federal. Brasília.

Brasil. (2014b). Tribunal de Contas da União. Referencial para avaliação de governança em políticas públicas. Brasília. Brasil. (2016) Tribunal de Contas da União. Referencial para avaliação da governança do Centro de Governo. Brasília. OECD (2014) Centre stage: driving better policies from the Center of Government. Paris: OECD.

OECD. (2016) Panorama de las administrations públicas: América Latina y el Caribe 2017. Paris: OECD. 
PALAVRAS-CHAVE: centro de governo; arranjo de governança; coordenação de políticas públicas; democracia; Brasil.

\section{Como funciona a governança do poder executivo no Brasil democrático? Uma análise do Centro de Governo}

RESUMO Introdução: O objetivo deste artigo é analisar como o Centro de Governo (CdG) atua como unidade responsável pela condução da agenda presidencial no Brasil contemporâneo. Materiais e Métodos: O estudo aplicou a abordagem teórica do CdG como um arranjo de governança e utilizou dados qualitativos e quantitativos para atingir seu objetivo. Além da revisão bibliográfica sobre a literatura e documentos oficiais, o estudo sintetiza e aprofunda dados empíricos e informações de um projeto de pesquisa conjunto abrangendo o período de estabilidade política no Brasil, de 1995 a 2014, quando os presidentes eleitos finalizaram seus mandatos. Resultados: Os achados empíricos confirmam que CdG é fenômeno dinâmico e flexível. Isso coloca em perspectiva crítica a abordagem normativa da "boa governança" que supervaloriza sua dimensão técnica e negligência seu aspecto político. Discussão: Os resultados da pesquisa lançam luz sobre a importância da relação entre política e políticas públicas, ao demonstrar que a configuração e as funções do Centro de Governo variam devido a múltiplas causas, cada agenda de política pública do presidente é implementada de forma diferente e as políticas priorizadas seguem uma lógica de coordenação única dentro do governo federal brasileiro.

This is an Open Access article distributed under the terms of the Creative Commons Attribution Non-Commercial License which permits unrestricted non-commercial use, distribution, and reproduction in any medium provided the original work is properly cited.

A produção desse manuscrito foi viabilizada através do patrocínio fornecido pelo Centro Universitário Internacional Uninter à Revista de Sociologia e Política.

\section{Contexto de pesquisa}

O Centro de Governo ( $\mathrm{CdG}$ ) tem ganhado destaque entre acadêmicos, dirigentes públicos e organizações multilaterais, considerando que o setor público vem enfrentando um conjunto de desafios críticos de políticas públicas em um contexto de dinâmicas mudanças econômicas, políticas, sociais e tecnológicas em todo o mundo. Além disso, as expectativas e demandas crescentes dos cidadãos por melhorias nos serviços públicos pressionam os políticos a inovar em termos de arranjos de governança para fortalecer a implementação e a eficácia das políticas.

\section{Evidências antes do estudo}

Apesar de sua importância, há poucas pesquisas sobre a governança do Poder Executivo e coordenação de políticas públicas no Brasil. A maior parte da literatura sobre o CdG vem de organizações multilaterais e de área de controle, publicações predominantemente normativas e fundamentados em diferentes contextos político-administrativos. Essa abordagem geralmente carece de base teórica sólida e evidências empíricas válidas sobre o que é o CdG e como ele funciona. Esses esforços visam emular boas práticas para pressionar a administração pública por um melhor desempenho e maior nível de accountability. No entanto, ao negligenciar a dinâmica democrática e as realidades administrativas específicas, eles podem limitar a capacidade de fornecer uma recomendação viável e, assim, tendem a ser ineficazes ou até arriscados.

\section{Valor agregado deste estudo}

O presente estudo analisa a estrutura e os padrões de funcionamento do arranjo de governança do CdG brasileiro, de 1995 a 2014, com base no conhecimento de pesquisa empírica e científica. Aborda o que é, de fato, o Centro de Governo, como se modifica ao longo do tempo, seus papéis fundamentais e como o CdG desempenha as tarefas formais e informais no complicado sistema político e administrativo do Brasil. A principal conclusão é que o Centro de Governo é um arranjo de governança flexível, complexo e dinâmico que muda continuamente devido aos estilos presidenciais, objetivos das políticas públicas e conjunturas política e econômica.

Apesar de sua estrutura mutável, a Casa Civil e os Ministérios do Planejamento e da Fazenda sempre fizeram parte do CdG brasileiro. Esses cargos tendem a ser ocupados principalmente por profissionais de perfil mais técnico e não partidário, seguidos dos correligionários do presidente. Dentre as funções típicas, a coordenação, o planejamento e a gestão estratégica da agenda de prioridades do presidente são predominantes nas atividades do Centro de Governo. No entanto, a liderança e o engajamento das unidades integrantes do CdG variam em função do grau de priorização investido na agenda estratégica e de autonomia dado a elas pelo presidente. 


\section{Implicações das evidências disponíveis}

O artigo coloca em perspectiva crítica a abordagem de "boa governança" do Centro de Governo. Os achados levantam objeções em relação aos pacotes de reformas impostos por agentes externos que desconhecem a variedade de interpretações sobre esse fenômeno e o contexto institucional no qual a governança do Poder Executivo está inserida. Propostas baseadas em boas práticas servem para estimular e pressionar a administração pública por um melhor desempenho e mais accountability, no entanto, estabelecer em lei a rigidez na estrutura e nas funções do CdG pode ser inócuo e problemático. Porque ignora a urgência das prioridades de políticas públicas do presidente e um mundo repleto de problemas e pressões sociais em constante mudança. Além disso, a abordagem normativa parte de uma positividade embutida em um suposto consenso e, sobretudo, de pressupostos de que a adoção de ideias e práticas bem-sucedidas em realidades políticas e administrativas díspares alcançaria automaticamente os mesmos resultados.

Em síntese, o CdG não é apenas um órgão técnico, mas, sobretudo, político. Construir autoridade com capacidade para implementar a agenda presidencial exige um alto nível de investimento em recursos, instituições, aprendizado e negociação para coordenar atores-chave envolvidos e relacionamentos dentro e fora do governo. Trata-se de uma questão de ação coletiva, que sempre envolve a compreensão da dimensão política na co-criação de soluções para o setor público. Portanto, este artigo conclui que engessar o Centro de Governo pode prejudicar a capacidade do Executivo de lidar com os chamados wicked problems, ou seja, problemas complexos, transversais e multicausais, como a atual crise do COVID-19, que exigem respostas do Estado nada simplórias em sociedades democráticas e em um ambiente de rápidas mudanças. 